Citation: Córdova-Ballona, L., Rincón-Ramírez, J. A., LagunesEspinoza, L. del C., De la Cruz-Pérez, A., Moscoso-Ramírez, P. A., \& Sánchez-Soto, S. (2021). Population Fluctuation of Disonycha teapensis Blake (Coleoptera: Chrysomelidae) in Crotalaria longirostrata Hook. \& Arn. (Fabales: Fabaceae) in Huimanguillo, Tabasco, Mexico. Agro Productividad. https://doi.org/ 10.32854/agrop. v14i10.2087

Editor in Chief: Dr. Jorge Cadena Iñiguez

Received: April 21, 2021. Accepted: September 28, 2021.

Published on-line: November 8, 2021

This work is licensed under a Creative Commons Attribution-NonCommercial 4.0 International license.

\section{Population Fluctuation of Disonycha teapensis Blake (Coleoptera: Chrysomelidae) in Crotalaria longirostrata Hook. \& Arn. (Fabales: Fabaceae) in Huimanguillo, Tabasco, Mexico}

\author{
Córdova-Ballona, Leonides ${ }^{1}$; Rincón-Ramírez, Joaquín A. ${ }^{1}$; Lagunes-Espinoza, Luz del C. ${ }^{1}$; De la \\ Cruz-Pérez, Aracely ${ }^{2}$; Moscoso-Ramírez, Pedro A. ${ }^{1}$; Sánchez-Soto, Saúl ${ }^{1^{*}}$ \\ ${ }^{1}$ Colegio de Postgraduados, Campus Tabasco. Periférico Carlos A. Molina s/n, H. Cárdenas, Tabasco, \\ México. \\ 2 Universidad Juárez Autónoma de Tabasco, División Académica de Ciencias Biológicas. Carretera \\ Villahermosa-Cárdenas km 0.5, Villahermosa, Tabasco, México. \\ * Correspondence: sssoto@colpos.mx
}

\begin{abstract}
Objective: To establish the population fluctuation of Disonycha teapensis adults and larvae and to determine its relationship with the amount of damaged foliage, temperature, and precipitation.

Methodology: The study was carried out in a $n=48$ Crotalaria longirostrata plant crop. The following data was recorded every week: number of adults and larvae, damaged leaflets percentage, plant phenology, temperature, and precipitation. Based on these data, monthly averages were calculated, and correlation analysis were performed between the population fluctuation of $D$. teapensis and the fluctuation of the damaged foliage percentage, temperature, and precipitation.

Results: All the phenological stages of $C$. longirostrata were affected by the pest, which showed a constant population growth. The population fluctuation resembled the fluctuation of the damaged foliage percentage, with a significant positive correlation between both variables. Regarding temperature and precipitation, the correlation was negative but not significant; therefore, the relationship between population fluctuation and these climatic factors is not clear.

Study Limitations: It was not possible to conduct the study for a full year.

Conclusions: The population development of D. teapensis depends on the increase in the amount of foliage of its host plant. This insect attacks plants in all their phenological stages and the amount of damaged foliage is considerable.
\end{abstract}

Keywords: Chrysomeloidea, population, chipilin.

\section{INTRODUCTION}

Disonycha teapensis (Coleoptera: Chrysomelidae) was originally described by Blake (1933), based on adult specimens from Teapa, Tabasco, Mexico. Adults are about $7.5 \mathrm{~mm}$ long, elongated and oblong; other aspects include: a yellow body (in preserved specimens) with dark antennae, except for the mostly pale basal segments; they have two dark spots on the anterior part of the pronotum and three dark longitudinal bands on the elytra (Blake, 1933).

D. teapensis belongs to the alternata group, whose females have a similar irregular pronotum and traces of elytral costae; D. teapensis is more 
similar to D. pluriligata, from which it differs by the shape of the aedeagus (Blake, 1955). D. teapensis is reported only in Mexico (Blake, 1955), with records in Tabasco (Blake, 1933, 1955), San Luis Potosí (Blake, 1955), Oaxaca (Furth, 2013), and Tamaulipas (Sánchez-Reyes et al., 2015).

In La Chontalpa, Tabasco, adults and larvae of D. teapensis damage the leaves of Crotalaria longirostrata (Fabaceae), a native species commonly found in home gardens. Its foliage is used in regional gastronomy. Although its cultivation has not yet been developed, it is considered a valuable phytogenetic resource that should be preserved and studied to determine its use and production potential (Lagunes-Espinoza, 2019). Therefore, the objective of this study was to find out the population fluctuation of D. teapensis, taking into consideration the phenological stages of C. longirostrata, as well as to determine its relationship with the fluctuation of the amount of damaged foliage and the climatic conditions - such as temperature and precipitation - in this area of western Tabasco, Mexico.

\section{MATERIALS AND METHODS}

\section{Study Site}

The study was carried out on a C. longirostrata crop established at El Recinto, Tabasco Campus, Colegio de Postgraduados, Huimanguillo, Tabasco (1758' 37.10” N, $93^{\circ} 23^{\prime}$ 10.57 " W). The local climate is hot-humid with copious rainfall from June to October. The average temperature is $26^{\circ} \mathrm{C}$ and the average annual rainfall is $2000 \mathrm{~mm}$ (INEGI, 2001). The crop consisted of $n=48$ plants arranged in four rows, with 12 plants per row. Each row consisted of a $20-\mathrm{cm}$ high, 20-cm wide, and 10-m long furrow. The distance between rows was $1.5 \mathrm{~m}$ and the distance between plants was $0.9 \mathrm{~m}$. Hand weeding was the only method used to maintain the crop; no chemical products were applied.

\section{Insect Count and Damaged Foliage}

In order to determine the population fluctuation of D. teapensis, weekly counts of the adults and larvae present in each plant were carried out, from the seedling stage to the fruiting stage, from September 24, 2018 to February 27, 2019. At the same time, the weekly damage to the foliage was quantified, counting the total number of leaflets and the number of damaged leaflets in each plant. The rule of three was used to calculate the damaged foliage percentage. D. teapensis adults bite the leaflets destroying the leaf blade; they usually start at the edge of the leaflets and then move on to the midrib, on one or both sides of the leaflet (Figure 1A). They also pierce the leaves, but this is less frequent. Small larvae scrape the leaf tissue, while the damage caused by the biggest larvae is similar to the damage caused by the adults (Figure $1 \mathrm{~B}, \mathrm{G}$ ).

\section{Phenological Data}

The number of plants in the different development stages (seedling, vegetative development, flowering or fruiting stages) was recorded weekly, in order to compare the population fluctuation with the plant phenology. This data was used to determine the percentage of plants in each stage per month. In this study, we considered that the seedling 

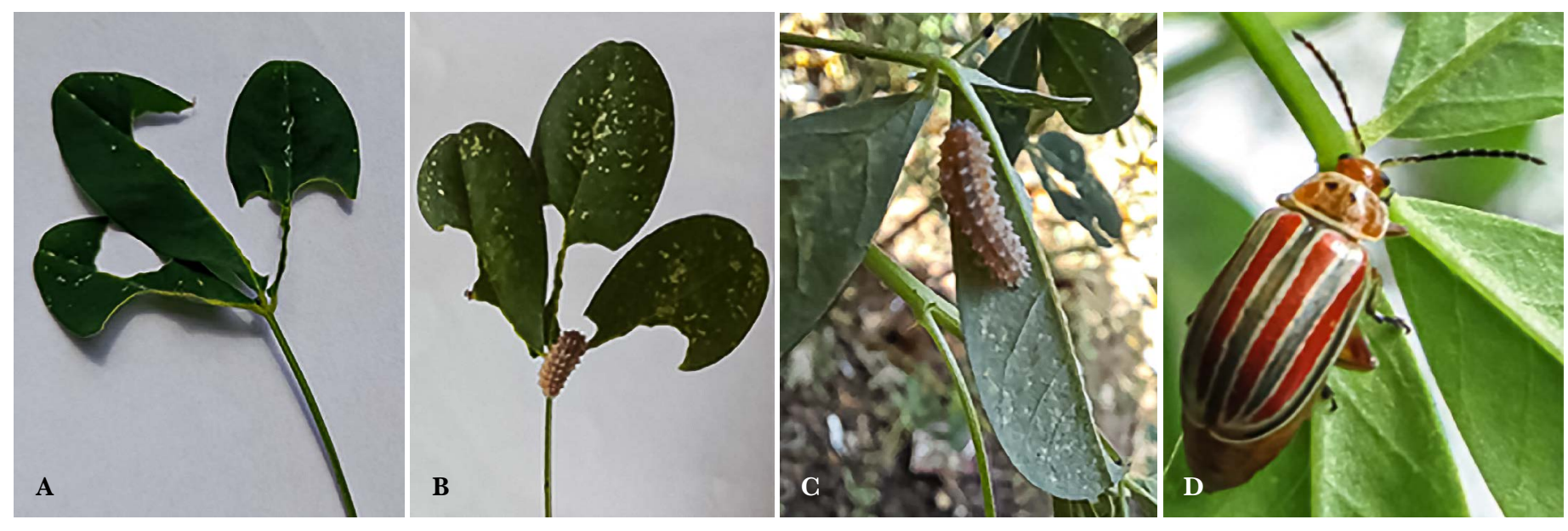

Figure 1. Crotalaria longirostrata leaf damaged by the adult (A) and larvae (B-G) and (D) Disonycha teapensis adult.

stage starts at the germination and ends when the first true leaves are formed and that the vegetative development starts when the first leaves are fully developed and ends when the flowering begins.

\section{Temperature and Precipitation Data}

The temperature and precipitation data (September 2018-February 2019) were obtained from the meteorological station of the Instituto Nacional de Investigaciones Forestales, Agrícolas y Pecuarias (INIFAP), located approximately $14 \mathrm{~km}$ away from the study site.

\section{Statistical Analysis}

Monthly averages were calculated based on the weekly data about the number of individuals of $D$. teapensis and percentage of damaged foliage; those averages were used to draw graphs of the said insect's population fluctuation and the damage to the foliage. The daily temperature $\left({ }^{\circ} \mathrm{C}\right)$ and precipitation $(\mathrm{mm})$ data were used to calculate monthly averages, from which fluctuation graphs of these climatic factors were drawn. The Statgraphics Plus Software version 5.1 was used to carry out a Pearson correlation analysis between the population fluctuation values of $D$. teapensis (adults plus larvae) and the fluctuation values of the damaged foliage, temperature, and precipitation percentages.

\section{RESULTS AND DISCUSSION}

\section{Presence of $D$. teapensis}

During the study period, 1,048 adults and 100 larvae of D. teapensis were counted. We were unable to determine the instar or stage of the registered larvae; however, based on their size, most of the individuals were in an advanced stage of development. Smaller (especially recently-hatched) larvae may have gone unnoticed during plant review; therefore, they were not accounted for in the weekly counts. Consequently, the number of larvae registered could have been lower than the number of adults. In addition, the adults are more visible as a result of their coloration, size, and greater mobility. However, it is likely that more 
adults were registered than larvae mainly as a result of the possible increase in the adult population. Considering that this species is capable of flight, this increase could have been the result of the arrival of individuals from other sites. Additionally, in a study carried out in Florida, United States, D. leptolineata Blatchley larvae were observed only once on Itea virginica, their host plant (Watts, 1990).

\section{Population Fluctuation}

Although less larvae than adults were registered, the population behavior of both development stages was similar (Figure 2A). When comparing the population fluctuation (Figure 2A) with the development phases of C. longirostrata plants (Figure 2B), we observed that $D$. teapensis was present in all phenological stages, although only some adults were observed in the seedling stage. Adults began the colonization of the plants in the month of October, when $50.36 \%$ of the plants already had fully developed leaves. This behavior is similar to that of D. leptolineata in Florida, whose adults begin to feed on the leaves of I. virginica when the plants are in their initial phase of development (Watts, 1990). The D. teapensis larvae were first observed in November, when the plants were just over 30 days old and $89.82 \%$ were in the vegetative development phase (Figure 2A, B). The initial larvae population - in the first stages of development stage - might have been present since mid-October, since the larvae registered in November were in an advanced development stage and the larval stage of other Disonycha species lasts 13 to 36 days (Cordo et al., 1984; Watts, 1990).

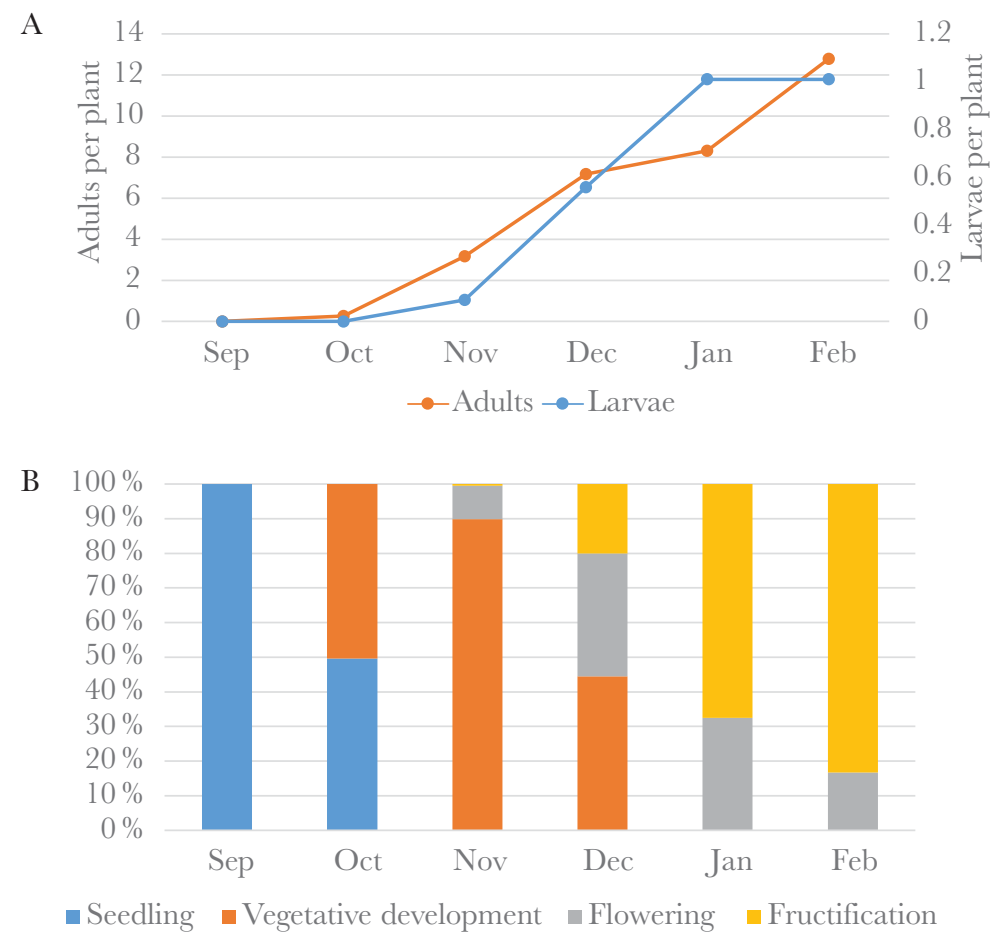

Figure 2. Population fluctuation of D. teapensis adults and larvae (A). Percentage of C. longirostrata plants per phenological stages during the study period (B). Huimanguillo, Tabasco, September 2018 to February 2019. 
From November, the population of adults and larvae began to increase steadily (Figure 2A), as a result of the increase in the amount of foliage, a product of vegetative development (Figure 2B). From December - when 55.56\% of the plants were already in the flowering and fruiting stages-, the amount of foliage available allowed the constant growth of the D. teapensis population; it kept growing, until it reached its highest density at the end of February - when $83.33 \%$ of the plants were in the fruiting stage and the experiment ended (Figure 2A, B).

The Pearson correlation analysis showed a highly significant positive correlation between the insect population fluctuation and the fluctuation of the damaged foliage percentage (Table 1, Figure 3A). This means that there exists a direct relationship between the two variables; therefore, the amount of damaged foliage increased as the quantity of insects increased.

Temperature and precipitation had a negative correlation without statistical significance (Table 1); therefore, there is no clear relationship between the population fluctuation of $D$. teapensis and these climatic factors. Long-term studies — or at least a full year study - are necessary to determine if there is a relationship between climatic factors and the impact of this insect. Therefore, the temperatures $\left(23-29^{\circ} \mathrm{C}\right)$ and the rainfall $(7-30 \mathrm{~mm})$ that were recorded (Figure 3B) did not limit the life cycle and population development of $D$. teapensis. During the study, a maximum of up to $30 \%$ of damaged leaflets was recorded; however, the percentage may be higher, it we take into account that the pest population continued to grow during the last month of the study (Figure 3A).

Table 1. Pearson's correlation analysis between the population fluctuation of Disonycha teapensis and the fluctuation of the percentage of damaged foliage, temperature, and precipitation.

\begin{tabular}{l|c|c}
\multicolumn{1}{c|}{ Variable } & Correlation coefficient & Probability \\
\hline Damaged foliage $(\%)$ & 0.946 & 0.004 \\
\hline Temperature $\left({ }^{\circ} \mathrm{C}\right)$ & -0.646 & 0.165 \\
\hline Precipitation $(\mathrm{mm})$ & -0.202 & 0.701 \\
\hline
\end{tabular}

A

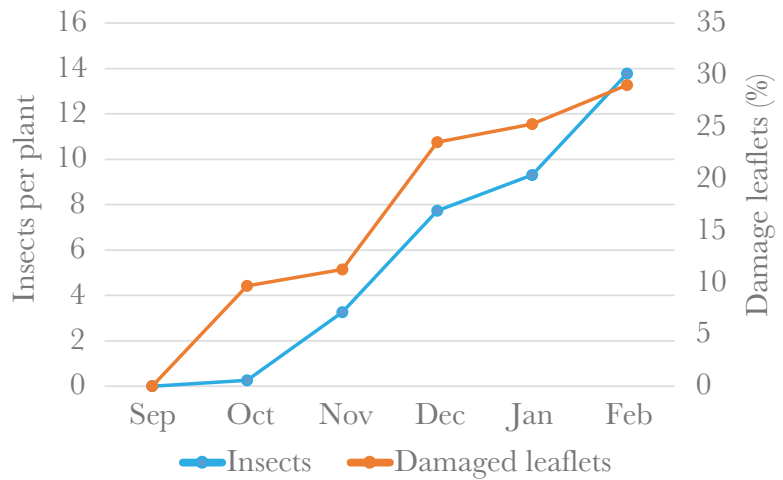

B $35-35$

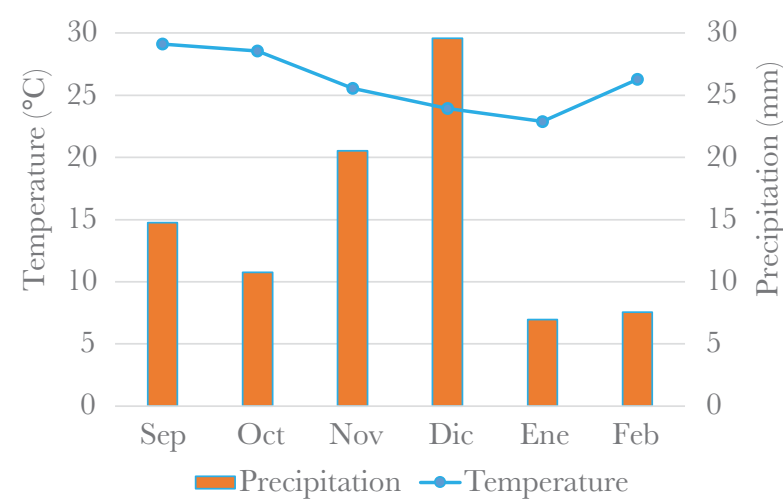

Figure 3. Population fluctuation of D. teapensis (adults plus larvae) and the damaged leaflet percentage (A). Temperature fluctuation and precipitation (B). Huimanguillo, Tabasco, September 2018 to February 2019. 


\section{CONGLUSIONS}

Since $D$. teapensis feeds on the leaves of $C$. longirostrata, the development of its populations depends on the increase in the amount of the foliage of its host plant. D. teapensis attacks plants in all their phenological stages and it causes a considerable amount of damage to their foliage. We suggest continuing with this type of studies, throughout all the seasons of the year, in order to clarify the relationship between this insect's population fluctuation and the temperature and precipitation fluctuations.

\section{AGKNOWLEDGMENTS}

The first author would like to thank the Consejo Nacional de Ciencia y Tecnología (CONACyT) for the scholarship granted to carry out her doctoral studies; the authors would like to thank the Colegio de Postgraduados for the financial support to carry out the work and to Ms. Sabel Barrón Freire (engineer), from the Instituto Nacional de Investigaciones Forestales, Agrícolas y Pecuarias, for her support with the climatological data.

\section{REFERENGES}

Blake, D.H. (1933). Revision of the beetles of the genus Disonycha occurring in America north of Mexico. Proceedings of the United States National Museum 82(2969): 1-66. Doi: 10.5479/si.00963801.82-2969.1

Blake, D.H. (1955). Revision of the vittate species of the chrysomelid beetle genus Disonycha from the Americas south of the United States. Proceedings of the United States National Museum. 104(3338): 1-86. Doi: 10.5479/si.00963801.104-3338.1

Cordo, H.A., Deloach, C.J., Ferrer, M. (1984). Biology and larval host range of the flea beetle Disonycha argentinensis (Coleoptera: Chrysomelidae) on alligatorweed in Argentina. Annals of the Entomological Society of America. 77(2): 134-141.

Furth, D.G. (2013). Diversity of Alticinae in Oaxaca, Mexico: A preliminary study (Coleoptera, Chrysomelidae). ZooKeys 332. 1-32. doi:10.3897/zookeys.332.4790.

INEGI. (2001). Síntesis de información geográfica del estado de Tabasco. Disponible en:http://internet. contenidos.inegi.org.mx/contenidos/productos/prod_serv/contenidos/espanol/bvinegi/productos/histor icos/2104/702825223939/702825223939 2.pdf.

Lagunes-Espinoza, L.C. (2019). Chipilín y chiles: tesoros escondidos de la cocina Chontal. Diálogos. 58. 10-13.

Sánchez-Reyes, U.J., Niño-Maldonado, S., Meléndez-Jaramillo, E., Gómez-Moreno, V.C., Banda-Hernández, J.E. (2015). Riqueza de Chrysomelidae (Coleoptera) en el Cerro El Diente, San Carlos, Tamaulipas, México. Acta Zoológica Mexicana. 31(1). 10-22.

Watts, J.R. (1990). Eggs, larvae and biological notes on Disonycha leptolineata Blatchley (Coleoptera: Chrysomelidae). Insecta Mundi. 4(1-4). 93-9. 